\title{
Kajian Penerapan Rekayasa Sosial Dengan Pendekatan Berbasis Masyarakat Terhadap Rencana Pembangunan RDNK
}

\author{
Siti Alimah" ${ }^{* 1}$, Mudjiono', Heni Susiati ${ }^{1}$, Ristiana Dwi Hastuti ${ }^{2}$, Dimas Irawan ${ }^{2}$, Adi Nugraha ${ }^{3}$ \\ ${ }^{1}$ Pusat Kajian Sistem Energi Nuklir (PKSEN)-BATAN,Jl. Kuningan Barat, Jakarta Selatan, Indonesia \\ ${ }^{2}$ Pusat Diseminasi dan Kemitraan (PDK)-BATAN, Jl. Lebak bulus Raya, Jakarta Selatan, Indonesia \\ ${ }^{3}$ Biro Hukum Humas dan Kerjasama (BHHK)-BATAN, JI. Kuningan Barat, Jakarta Selatan, Indonesia
}

\section{INFORMASI ARTIKEL}

Riwayat Artikel:

Diterima:

06 November 2019

Diterima dalam bentuk revisi:

27 November 2019

Disetujui:

29 November 2019

\section{Kata kunci:}

Rekayasa sosial

RDNK

Diseminasi

Iptek nuklir

Kelompok masyarakat

\begin{abstract}
ABSTRAK
KAJIAN PENERAPAN REKAYASA SOSIAL DENGAN PENDEKATAN BERBASIS MASYARAKAT TERHADAP RENCANA PEMBANGUNAN RDNK. Reaktor Daya Non Komersial (RDNK) yang direncanakan dibangun di Kawasan Puspiptek Serpong, akan berdampak bagi masyarakat sekitar kawasan. Untuk meminimalkan masalah sosial perlu dilakukan penerapan rekayasa sosial dengan pendekatan berbasis masyarakat. Rekayasa sosial dilakukan dengan pemberian informasi dan peningkatan pemahaman teknologi nuklir, rencana pembangunan RDNK serta pemanfaatannya kepada masyarakat. Tujuan kajian ini adalah membentuk kelompok masyarakat melalui pendekatan yang sesuai untuk meningkatkan penerimaan masyarakat dengan pelibatan aktif dalam kegiatan diseminasi. Metodologi yang digunakan adalah melalui tinjauan pustaka, pelibatan aktif dari masyarakat melalui wawancara dan diskusi kelompok stakeholder di beberapa kelurahan sekitar Kawasan Puspiptek Serpong, selanjutnya dilakukan analisis. Hasil penelitian menunjukkan bahwa pendekatan komunikasi interpersonal akan meningkatkan kesadaran masyarakat terhadap pentingnya pemanfaatan iptek nuklir. Terdapat perubahan positif dari masyarakat terhadap pemahaman iptek nuklir sebelum dan sesudah edukasi. Pemahaman ini dimengerti oleh masyarakat dengan usia bervariasi yaitu 30 70 tahun, sebagian besar berpendidikan SLTA ke atas dan memiliki pekerjaan di luar pemerintah. Dalam penelitian ini juga diperoleh kelompok masyarakat yang bersedia terlibat dalam kegiatan diseminasi yang tersebar di 8 kelurahan yaitu Setu, Muncul, Kademangan, Keranggan, Cibogo, Bakti Jaya, Pengasinan, dan Pabuaran.
\end{abstract}

\begin{abstract}
STUDY OF SOCIAL ENGINEERING IMPEMENTATION WITH A COMMUNITY-BASED APPROACH TO THE RDNK DEVELOPMENT PLAN. The Non-Commercial Power Reactor (RDNK) that is planned to be built in the Puspiptek Serpong Area, will have an impact on the community around the area. To minimize social problems, it is necessary to apply social engineering using a community-based approach. Social engineering is done by providing information and increasing understanding of nuclear technology, RDNK development plan and its utilization to the public. The aim of this assessment is to form community groups through an appropriate approach to increase community acceptance by active involvement in dissemination activities. The methodology used is through literature review, active involvement from the community through interviews and group discussions with stakeholders, in several villages around the Serpong Puspiptek Area, then an analysis is conducted. The results showed that the interpersonal communication approach would increase public awareness of the importance of utilizing nuclear science and technology. There are positive changes from the community towards understanding nuclear science and technology before and after education. This understanding is understood by people with varying ages of 30-70 years, with most of the education being senior high school and above, and most having jobs outside the government. In this study also obtained community groups who are willing to be involved in dissemination activities that are scattered in 8 village, namely Setu, Muncul, Kademangan, Keranggan, Cibogo, Bakti Jaya, Pengasinan, and Pabuaran.

Keywords : social engineering, RDNK, dissemination, nuclear science and technology, community groups.
\end{abstract}

\section{PENDAHULUAN}

BATAN berencana membangun dan mengoperasikan Reaktor Daya Non Komersial (RDNK). RDNK yang direncanakan dibangun selain menghasilkan listrik juga digunakan untuk penelitian proses aplikasi panas serta sebagai sarana penelitian dan pengembangan teknologi High Temperature Gas-cooled 
Reactor (HTGR) di Indonesia. Pembangunan RDNK adalah salah satu sarana untuk meningkatkan kemampuan penguasaan teknologi Pembangkit Listrik Tenaga Nuklir (PLTN) dan merupakan jembatan untuk pembangunan PLTN skala besar. RDNK direncanakan dibangun di Kawasan Puspiptek Serpong.

Proyek pembangunan RDNK merupakan hal yang baru bagi masyarakat, oleh karena itu masing-masing individu mempunyai persepsi yang berbeda[1]. Pembangunan RDNK akan mengubah lingkungan dan sosial ekonomi masyarakat sekitar Kawasan Puspitek Serpong. Dari hasil penelitian sebelumnya diperoleh tingkat penerimaan masyarakat terhadap rencana pembangunan RDNK di sekitar kawasan Puspitek Serpong sebesar 75\%. Sedangkan yang menolak kehadiran RDNK sebesar 7\% dan yang tidak menjawab $18 \%$ [2].

Seperti diketahui, rencana pembangunan suatu proyek dapat menimbulkan dampak positif atau negatif terhadap lingkungan. Pembangunan dan pengoperasian RDNK mempunyai komitmen untuk mengelola lingkungan hidup dengan baik, sehingga pembangunan berkelanjutan dapat terus dilaksanakan. Keberadaan RDNK harus dapat menjamin keberlanjutan sosial (social sustainability), keberlanjutan ekonomi (economic sustainability) dan keberlanjutan fungsi lingkungan hidup (environmental sustainability), karena integrasi ketiga dimensi tersebut merupakan pengambilan keputusan penting untuk mencapai tujuan pembangunan berkelanjutan [3-5].

Untuk menjamin keberlanjutan sosial, terdapat tantangan untuk memberi pemahaman pemanfaatan RDNK secara utuh kepada masyarakat. Implementasi rekayasa sosial diharapkan mengurangi dampak sosial yang dimungkinkan akan muncul seiring dengan pembangunan RDNK. Rekayasa sosial adalah campur tangan gerakan ilmiah dari visi ideal tertentu yang ditujukan untuk mempengaruhi perubahan social [1,6]. Gerakan ilmiah dimaksudkan sebuah gagasan atas perubahan tingkat/taraf kehidupan masyarakat demi tercapainya kesejahteraan dan kemandirian[6]. Pembangunan RDNK dapat mempengaruhi perubahan sosial, sehingga diperlukan rekayasa sosial. Implementasi rekayasa sosial terhadap pembangunan RDNK merupakan persepsi dan respon masyarakat yang riil, yang akan dilakukan dengan pelibatan aktif masyarakat terhadap pemahaman pemanfaatan RDNK.

Tujuan penelitian adalah membentuk kelompok masyarakat melalui pendekatan yang sesuai untuk meningkatkan penerimaan masyarakat dengan pelibatan aktif dalam kegiatan diseminasi.

\section{REKAYASA SOSIAL}

Masyarakat adalah makhluk sosial yang mengalami dinamika sosial, sehingga tidak selalu dalam kondisi statis. Berbagai masalah sosial dapat terjadi di kalangan masyarakat dan perlu upaya untuk memecahkan masalah tersebut sehingga memperbaiki sistem sosial yang mengarah pada kehidupan yang lebih baik. Masalah sosial dapat disebabkan kesalahan berfikir yang berkembang di masyarakat, sehingga diperlukan rekayasa sosial. Rekayasa sosial merupakan perubahan sosial yang direncanakan, berupaya mengubah masyarakat sesuai yang dikehendaki[7]. Rekayasa sosial tidak akan terlaksana, apabila terdapat kesalahan berfikir di masyarakat. Dalam rekayasa sosial terhadap rencana pembangunan RDNK diperlukan suatu tim dalam bentuk kelompok-kelompok, yang dapat membantu memberikan informasi, pemahaman dan pemanfaatan iptek nuklir kepada masyarakat lain.

Saat ini pembangunan PLTN (Pembangkit Listrik Tenaga Nuklir) di Indonesia belum terwujud. Beberapa penyebab penghambat terwujudnya pembangunan tersebut diantaranya kekhawatiran masyarakat tentang keamanan, keyakinan akan kemampuan membangun dan mengoperasikan PLTN dengan aman, serta dampak lingkungan jika terjadi kecelakaan[8]. Kekhawatiran tersebut menyebabkan beberapa masyarakat menolak dibangunnya PLTN. Untuk meningkatkan kepercayaan masyarakat terhadap kemampuan pengoperasian reaktor daya dengan aman, maka pemerintah melalui BATAN memprakarsai membangun RDNK. Pembangunan RDNK adalah jembatan pembangunan PLTN, merupakan proyek 
pekerjaan kompleks, dengan teknologi tinggi, mempunyai risiko tinggi, dan menggunakan peralatan yang didesain khusus. Upaya rekayasa sosial perlu dilakukan untuk mengantisipasi terjadinya masalah sosial terkait rencana pembangunan RDNK.

Rekayasa sosial dilakukan dengan teknik pengambilan data atau informasi pentingdari seseorang dengan pendekatan melalui mekanisme interaksi sosial[9]. Rekayasa sosial juga dapat dikatakan suatu teknik memperoleh data/informasi rahasia dengan mengeksploitasi kelemahan manusia dan memanfaatkan kenaifan kebanyakan orang[10]. Berbagai kelemahan manusia diantaranya [9]:

a. Rasa takut, sehingga yang bersangkutan akan langsung memberikan data atau informasi tanpa merasa sungkan;

b. Rasa percaya, sehingga yang bersangkutan akan langsung memberikan data atau informasi tanpa merasa curiga; dan

c. Rasa ingin menolong, sehingga yang bersangkutan akan langsung memberikan data atau informasi yang diinginkan tanpa bertanya lebih dahulu.

Rekayasa sosial dapat membuka ruang bagi masyarakat untuk aktualisasi, sehingga dapat terlihat dengan jelas peran masyarakat dalam proses perubahan sosial.

Perubahan sosial adalah perubahan yang terjadi dalam fungsi dan struktur masyarakat yang mempengaruhi sistem sosial, nilai, sikap, serta perilaku individü dan kelompok[11,12].

Penerapan rekayasa sosial dalam kajian ini melalui pemberian informasi, peningkatan pemahaman terkait teknologi nuklir, rencana pembangunan RDNK dan pemanfaatannya bagi masyarakat, sehingga meminimalkan masalah sosial. Informasi dan peningkatan pemahaman diberikan dengan rekayasa sosial melalui edukasi dengan diskusi aktif terhadap masyarakat dan kunjungan ke instalasi reaktor dan instalasi pengelolalaan limbah radioaktif, selain itu juga memanfaatkan media sosial. Sejumlah penelitian memperlihatkan adanya korelasi yang berkembang antara rekayasa sosial dan media sosial yang merupakan informasi pribadi dan organisasi[13,14]. Namun rekayasa sosial membutuhkan komitmen yang kuat dari pemangku kepentingan dan peran kuat masyarakat

secara

berkesinambungan[15].

\section{METODOLOGI}

Metode yang digunakan adalah studi literatur, pengumpulan data primer dan sekunder, selanjutnya dilakukan analisis. Studi literatur diperoleh dari berbagai referensi, artikel dan informasi lain terkait permasalahan. Data sekunder berdasar hasil yang diperoleh kajian tahun 2018 dan data dari instansi yang terkait dampak ekonomi, sosial dan budaya. Pengumpulan data primer dengan pelibatan aktif dari masyarakat yaitu wawancara dan diskusidengan stakeholder (tokoh masyarakat elit), yang dibentuk kelompok di beberapa kelurahan sekitar Kawasan Puspiptek Serpong. Parameter yang diukur dalam kegiatan ini adalah persepsi dan pemahaman pemanfaatan iptek nuklir.

Prinsip pendekatan berbasis masyarakat pada rekayasa sosial meliputi[1618]:

a. Aspirasi Masyarakat

Pendekatan berdasar kebutuhan, gagasan dan keinginan masyarakat, dimusyawarahkan dan mengakomodasi suara yang paling rasional serta dapat diterima. Dalam penelitian ini dilakukan dengan diskusi pada masyarakat yang berasal dari kelurahan Setu, Muncul, Kademangan, Keranggan, Cibogo, Bakti Jaya, Pengasinan dan Pabuaran, untuk memperoleh aspirasi masyarakat, sehingga terdapat proses partisipasi yang saling menguntungkan.

b. Kepentingan Masyarakat

Pendekatan mengutamakan kepentingan masyarakat, sehingga memberi manfaat kepada masyarakat. Diberikan pemahaman bahwa pembangunan RDNK memperhatikan kepentingan masyarakat, misal dalam tahap pembangunan akan melibatkan SDM masyarakat sekitar dan hasil RDNK juga untuk kepentingan masyarakat.

c. Kemampuan Masyarakat

Pendekatan mempertimbangkan tingkat kemampuan masyarakat sebagai dasar penentuan target sasaran. Dalam penelitian ini melibatkan masyarakat yang mempunyai kemampuan komunikasi dan pemahaman hasil litbang teknologi nuklir. 
d. Kerjasama Masyarakat

Pendekatan mempertimbangkan kebutuhan dan atas nama kelompok masyarakat, sehingga mampu mewujudkan kerjasama yang kuat dan mengakar di masyarakat. Kerjasama dalam hal melakukan kegiatan terkait peningkatan pemahaman dan pemanfaatan hasil litbang iptek nuklir sebagai contoh peningkatan ketahanan tanaman terhadap hama dan produktivitas petani.

Dalam penerapan rekayasa sosial ini dilakukan pembentukan kelompok aktif (mitra), dan mitra tersebut diharapkan dapat memberikan informasi dan pemahaman iptek nuklir dan pemanfaatannya, kepada beberapa masyarakat lain.

Tahapan rekayasa sosial meliputi[10]:

a. Pengumpulan informasi tentang target (masyarakat), kemudian membangun hubungan baik dengan target atau seseorang yang penting untuk kesuksesan kegiatan.

b. Identifikasi masyarakat dengan mengklasifikasikan dalam kategorisasi (contoh: tokoh masyarakat, struktur, masyarakat biasa), karakteristik (contoh : tokoh agama, ketua RT, ketua RW) dan pemetaan (contoh: kelurahan).

c. Hasil indentifikasi tersebut selanjutnya di lakukan pendekatan berbasis masyarakat.

d. Pelibatan kegiatan dengan maksud untuk peningkatan pengetahuan masyarakat melalui edukasi, sosialisasi dan kunjungan.

e. Pembentukan kelompok.

f. Evaluasi tindakan (mengukur capaian aktivitas mitra untuk melakukan pendekatan kepada masyarakat sekitar).

g. Peningkatan kapasitas pemahaman

Diagram Alir tahapan rekayasa sosial dalam kajian ini dapat dilihat dalam Gambar 1.

\section{Lokasi Kegiatan :}

Terdapat berbagai wilayah yang mengelilingi lokasi tapak RDNK Kawasan Puspiptek Serpong. Berdasar hasil kegiatan INSINAS rekayasa sosial tahun 2018, diperoleh respoden yang berasal dari beberapa kelurahan sekitar Kawasan Puspiptek Serpong diantaranya: Setu, Muncul, Kademangan, Keranggan, Cibogo, Bakti Jaya, Pengasinan, dan Pabuaran, sebagaimana terlihat dalam Gambar 2.

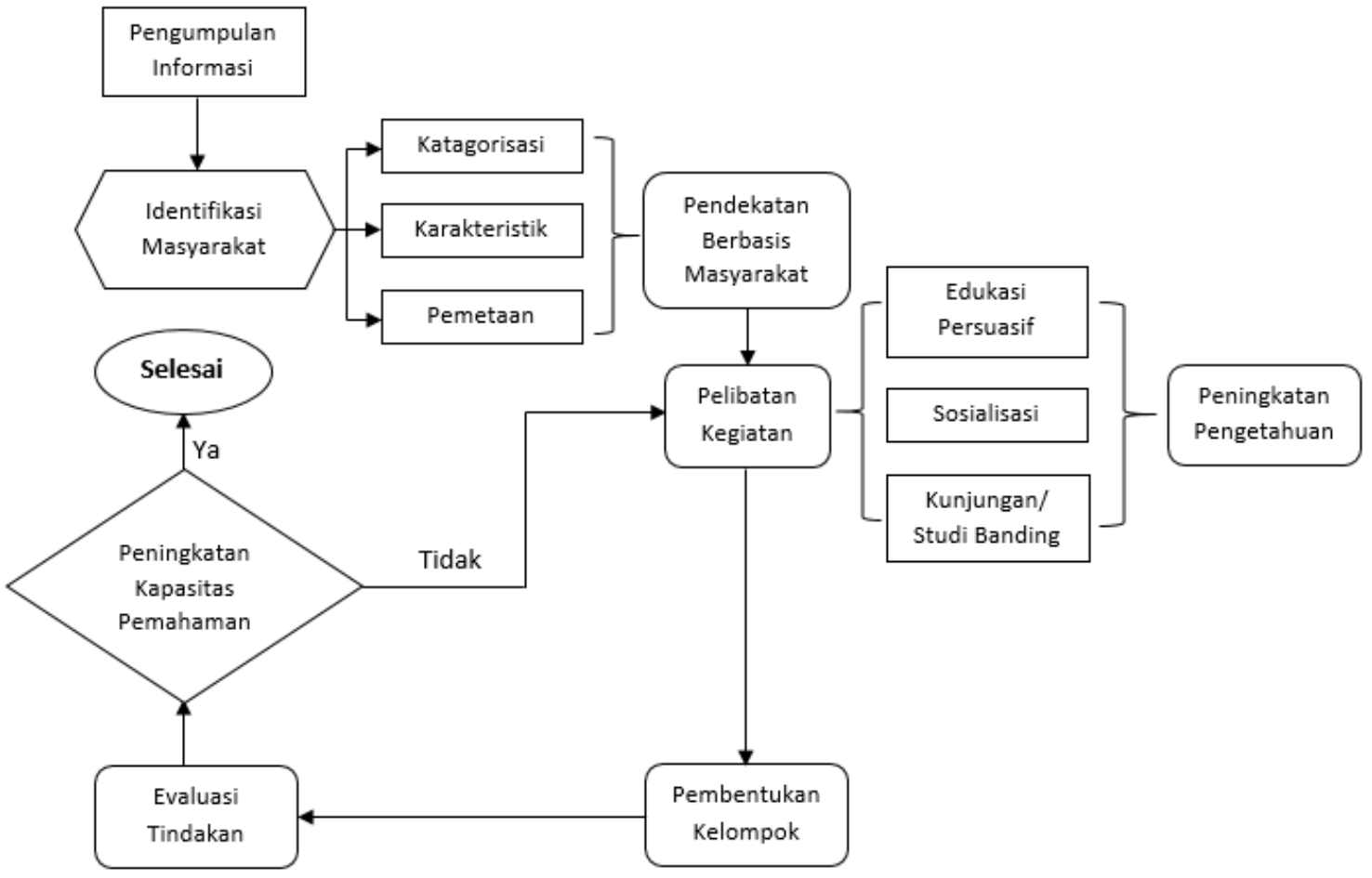

Gambar 1. Diagram Alir Tahapan Implementasi Rekayasa Sosial Terhadap Rencana Pembangunan RDNK. 


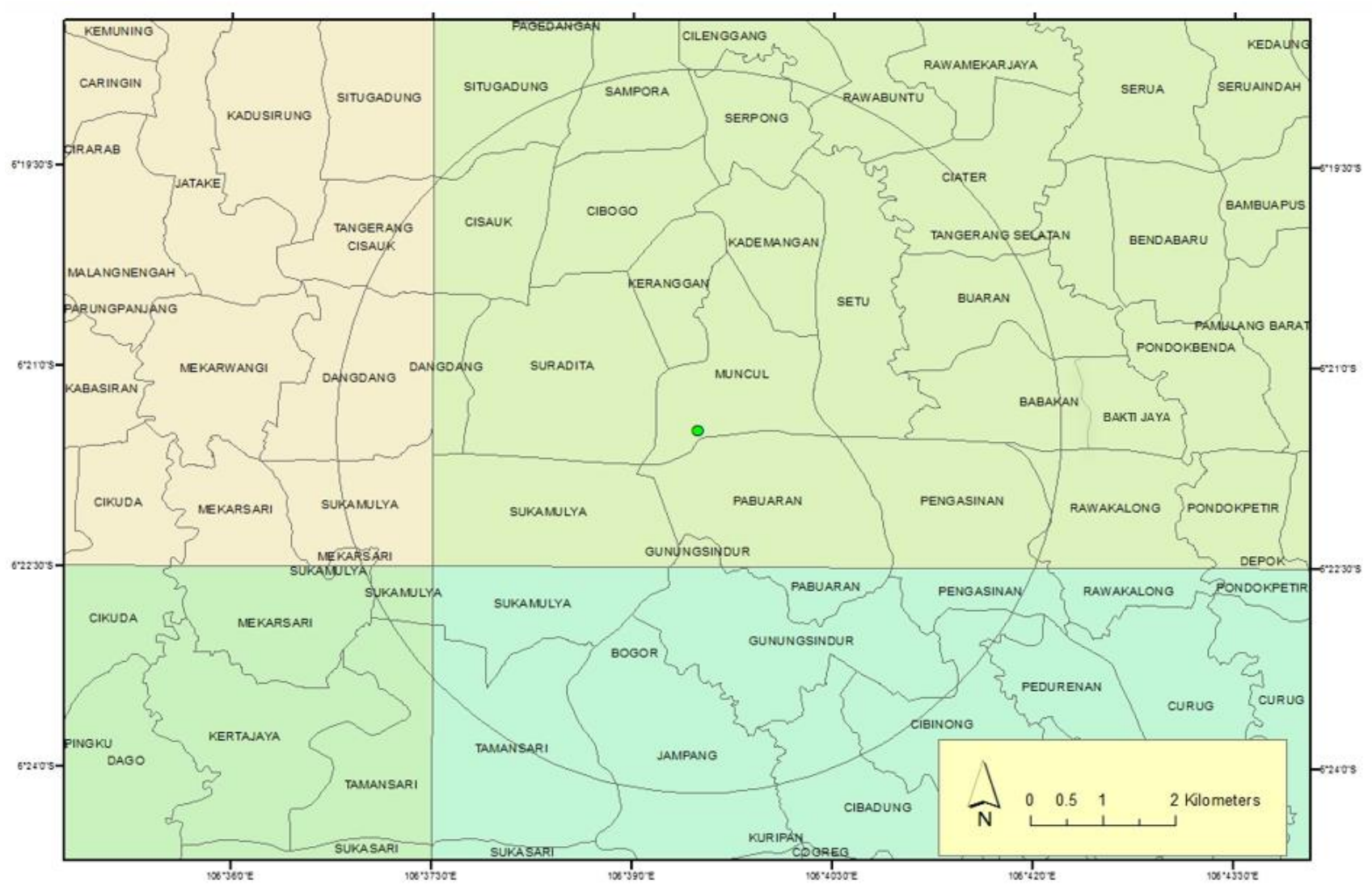

Gambar 2. Lokasi Kegiatan Penelitian[19,20].

\section{HASIL DAN PEMBAHASAN}

Dalam melaksanakan rekayasa sosial terhadap rencana pembangunan RDNK akan dilakukan berbasis masyarakat yaitu secara partisipatif, dialogis dan memperhatikan aspirasi masyarakat, menempatkan masyarakat baik secara perseorangan maupun kelompok sebagai subyek, penentu dan pelaku pembangunan.

Berdasar hasil pemetaan diperoleh mitra yang dilibatkan dalam kegiatan diseminasi yang tersebar di 8 kelurahan yaitu Setu, Muncul, Kademangan, Keranggan, Cibogo, Bakti Jaya, Pengasinan, Pabuaran.

Terhadap mitra ini, dilakukan edukasi persuasif dengan materi teknologi nuklir dan pemanfaatannya, serta peran BATAN bagi warga sekitar Kawasan Puspiptek Serpong. Berdasarkan hasil edukasi persuasif terhadap mitra tersebut, masyarakat memandang iptek nuklir dengan persepsi yang berbeda-beda. Terdapat peningkatan persepsi terkait pengetahuan PLTN sebagai teknologi nuklir, yang semula 53\% menjadi57\%, seperti terlihat pada Tabel 2. Sementara itu presepsi mitra terhadap radiasi menurun $37 \%$ menjadi $29 \%$. Disisi lain persepsi mitra bahwa iptek nuklir identik dengan bom mengalami penurunan. Persepsi mitra terhadap iptek nuklir untuk lainnya mengalami peningkatan

Tabel 2. Persepsi Kelompok Aktif (Mitra) Terhadap Iptek Nuklir Sebelum dan Sesudah Edukasi

\begin{tabular}{|l|c|c|}
\hline $\begin{array}{c}\text { Persepsi iptek } \\
\text { nuklir }\end{array}$ & $\begin{array}{c}\text { Sebelum } \\
\text { edukasi (\%) }\end{array}$ & $\begin{array}{c}\text { Sesudah } \\
\text { edukasi (\%) }\end{array}$ \\
\hline PLTN & 53 & 57 \\
\hline Radiasi & 37 & 29 \\
\hline Bom & 10 & 9 \\
\hline Lainnya & 0 & 5 \\
\hline
\end{tabular}

Pemahaman iptek nuklir ini dimengerti oleh masyarakat dengan usia bervariasi yaitu 30-40 tahun sebanyak 19\%, 41-50 tahun sebanyak 48\%, 51-60 tahun sebanyak $14 \%$ dan 61-70 tahun sebanyak 4,8\% (Gambar 3). Sebagian besar responden $(71 \%)$ yang memahami iptek nuklir berpendidikan SLTA ke atas (Gambar 4) dan memiliki pekerjaan di luar 
pemerintah (81\%) (Gambar 5). Grafik yang diarsir menunjukkan masyarakat yang belum paham iptek nuklir.

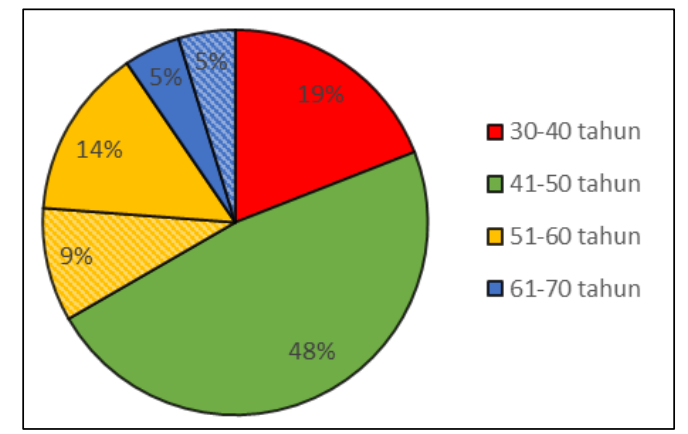

Gambar 3. Pemahaman Iptek Nuklir Berdasar Usia.

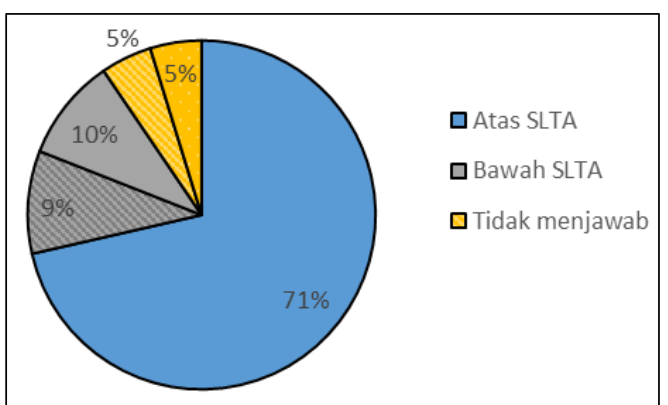

Gambar 4.Pemahaman Iptek Nuklir Berdasar Pendidikan.

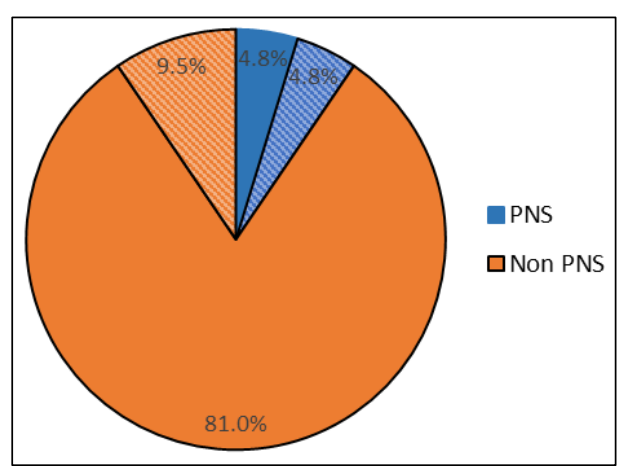

Gambar 5. Pemahaman Iptek Nuklir Berdasar Pekerjaan.

Sesudah edukasi melalui temu mitra terdapat peningkatan pengetahuan pemahaman pemanfaatan iptek nuklir yang semula $52,4 \%$ menjadi $85,7 \%$, seperti terlihat pada Tabel 3. Mitra BATAN selanjutnya didekatkan dengan fasilitas nuklir melalui kunjungan ke instalasi reaktor dan instalasi pengelolaan limbah radioaktif. Berdasar dialog langsung terhadap Mitra BATAN diperoleh persepsi positif terhadap teknologi nuklir. Informasi tersebut bertolak belakang dengan informasi awal sebelum dilakukan edukasi.
Tabel 3. Pemahaman Pemanfaatan Iptek Nuklir

\begin{tabular}{|l|c|c|}
\hline $\begin{array}{c}\text { Tingkat } \\
\text { Pemahaman }\end{array}$ & $\begin{array}{c}\text { Sebelum } \\
\text { Edukasi }\end{array}$ & $\begin{array}{c}\text { Sesudah } \\
\text { Edukasi }\end{array}$ \\
\hline Paham & 52,4 & 85,7 \\
\hline Tidak paham & 47,6 & 14,3 \\
\hline
\end{tabular}

Hasil evaluasi tindakandi peroleh 7 responden baru dari Kelurahan Pamulang Barat, Keranggan, Bakti Jaya, Muncul dan diketahui bahwa responden baru tersebut sudah mengetahui manfaat iptek nuklir.

Dengan dilakukannya perubahan sosial secara terencana maka diharapkan masyarakat atau pihak lain yang terkait akan mempunyai rasa memiliki dan tumbuh rasa bertanggung jawab terhadap aset RDNK jika dibangun sehingga keberlanjutan aset RDNK dapat terwujud. Oleh karena itu diperlukan pertemuan regular antara mitra dan BATAN untuk mengakomodasi kebutuhan yang diperlukan terkait upaya meningkatkan pemahaman iptek nuklir di masyarakat. Pertemuan dapat dilakukan di tengah-tengah masyarakat dalam bentuk yang disesuaikan dengan kondisi dan kebiasaan masyarakat sekitar.

Untuk mencapai hasil yang optimal dalam upaya meningkatkan penerimaan masyarakat terhadap rencana pembangunan RDNK, maka BATAN perlu meyakinkan kemanfaatannya kepada masyarakat melalui kegiatan informasi publik, edukasi publik dan pemanfaatan hasil litbangyasa. Wujud kepedulian kepada masyarakat dan lingkungan sekitar, senantiasa menjadi komitmen BATAN yang merupakan tanggung jawab sosial. Bentuk kepedulian yang selama ini sudah dilakukan BATAN, yaitu berupa Community Development (Comdev) namun masih terbatas. Program tersebut meliputi:

1. Bidang Pendidikan, yaitu: pengembangan kompetensi guru dan nuclear go to school di sekolah sekitar kawasan Puspiptek.

2. Bidang Pertanian dan Peternakan : bantuan benih padi, pakan ternak dan pemupukan yang bertujuan meningkatkan kemampuan usaha/ekonomi warga sekitar.

\section{KESIMPULAN}

Tahapan penerapan rekayasa sosial dengan pendekatan berbasis masyarakat meliputi pengumpulan informasi, identifikasi masyarakat, analisis, edukasi, sosialisasi dan 
kunjungan, pembentukan mitra dan evaluasi tindakan. Diperoleh mitra yang dilibatkan dalam kegiatan diseminasi yang tersebar di 8 kelurahan yaitu Setu, Muncul, Kademangan, Keranggan, Cibogo, Bakti Jaya, Pengasinan dan Pabuaran. Hasil edukasi persuasif terhadap mitra memperlihatkan bahwa terdapat peningkatan persepsi terkait pengetahuan PLTN sebagai teknologi nuklir, yang semula 53\% menjadi57\%. Terdapat peningkatan pemahaman pemanfaatan iptek nuklir yang semula $52,4 \%$ menjadi $85,7 \%$. Pemahaman ini dimengerti oleh masyarakat dengan usia bervariasi yaitu 30-70 tahun, sebagian besar berpendidikan SLTA ke atas dan memiliki pekerjaan di luar pemerintah. Diperoleh juga 7 responden baru dari Kelurahan Pamulang Barat, Keranggan, Bakti Jaya, Muncul dan diketahui bahwa responden baru tersebut sudah mengetahui manfaat iptek nuklir.

\section{UCAPAN TERIMA KASIH}

Terimakasih penulis sampaikan kepada Kementerian Riset, Teknologi dan Pendidikan Tinggi yang telah membiayai penelitian ini dalam skema pendanaan Program Insinas Gelombang II Tahun 2019. Selain itu, penulis juga mengucapkan terimakasih pada Kepala Pusat Kajian Sistem Energi NuklirBATAN yang telah memberikan arahan dalam kegiatan penelitian ini.

\section{DAFTAR ACUAN}

[1]. Mudjiono, Siti Alimah, Dimas Irawan, M. Busthomi, Heni Susiati, "Social Engineering to The Development Plan of Experimental Power Reactor (RDE)", Symposium of Emerging Nuclear Technology and Engineering Novelty (SENTEN) Palembang, 4-5th July 2018.

[2]. Mudjiono, Siti Alimah, Heni Susiati, Dimas Irawan, Moh. Busthomi, "Penerimaan masyarakat Sekitar Puspiptek Serpong Terhadap Rencana Pembangunan Reaktor Daya Eksperimental", Jurnal Pengembangan Energi Nuklir Vol. 20, No.2, 2018.

[3]. OECD, "Society and Nuclear Energy:Toward and Better Understanding", Organisation For Economic Co-Operation And Development, 2002. William Dahl, "Rekayasa Sosial", https://www.kompasiana.com/aboutlife/550d8f7d8 13311692db1e40b/rekayasa-sosial, diakses Mei 2019.

[4]. Peraturan Menteri Peraturan Menteri Perencanaan Pembangunan Nasional / Kepala Badan Perencanaan Pembangunan Nasional Republik Indonesia Nomor 7 Tahun 2018 tentang Koordinasi,
Perencanaan, Pemantauan, Evaluasi, Dan Pelaporan Pelaksanaan Tujuan Pembangunan Berkelanjutan.

[5].__ „Tujuan Pembangunan Berkelanjutan yang perlu diketahui oleh Pemerintah Daerah", https://www.uclg.org/sites/default/files/tujuansdgs.pdf, diakses 19 November 2019.

[6]. Richardus Eko Indrajit, "Seluk Beluk Teknik Social Engineerring”,https://www.idsirtii.or.id/doc/IDSIRT II-Artikel-sosial_engineering.pdf, diakses Mei 2019.

[7]. Said Romadlon, "Rekayasa Sosial Adopsi Teknologi Komunikasi (Internet) di kalngan Pondok Pesantren Muhammadiyah"Jurnal Lemlit Uhamka, https://docplayer.info/34267399-Rekayasa-sosialsocial-engineering-adopsi-teknologi-komunikasiinternet-di-kalangan-pondok-pesantrenmuhammadiyah.html, diakses Juni 2019

[8]. BATAN, "Rencana Pembangunan RDE di Indonesia"http://www.batan.go.id/index.php/id/ rencana-pembangunan-rde-di-indonesia, diakses Juli 2019.

[9]. Hussain Aldawoo. d and Geoffrey Skinner, "Reviewing Cyber Security Social Engineering Training and Awaraness Programs-Pitfalls and Ongoing Isssues”, Future Internet, MDPI, 18 March 2019.

[10]. Jason Pollack, Prakash Ranganathan, "Social Engineering and Its Impacts on Critical Infrastructure : A Comprehensive Survey", Int'1 Conf. Security and management, SAM'18.

[11]. Putri Nadiyatul Firdausi, "Analisis Dampak Sosial Dalam perencanaan Pembangunan: Rencana Revitalisasi Pasar Wates Wetan, Ranuyoso, Lumajang”, Jurnal kajian Ruang Sosial-Budaya, Vo. 1, No.2, 2018

[12]. Djazifah, NUR., "Proses Perubahan Sosial Di Masyarakat”, Yogyakarta: Lembaga Penelitian Dan Pengabdian Kepada Masyarakat Universitas Negeri Yogyakarta, 2012

[13]. Gross, R., \& Acquisti, A. (2005, November). Information revelation and privacy in online social networks. In Proceedings of the 2005 ACM workshop on Privacy in the electronic society (pp. 71-80).

[14]. Heidi Wilcox, Maumita Bhattacharya and Rafiqul Islam, "Social Engineering through Social Media: An Investigation on Enterprise Security", http://csusap. csu.edu.au/ $\sim$ mbhattac/pub/ATIS-2014-HW-MBRI.., diakses 20 November 2019.

[15]. Kementrian PUPR, "Rekayasa Sosial Pembangunan Bendungan”,

http://litbang.pu.go.id/berita/view/43/rekayasasosial-pembangunan-bendungan, Berita Katalog produk Iptek, diakses Mei 2019.

[16]. Endang Susilowati, Windiani, “ Pendekatan Rekayasa Sosial Dalam Pengelolaan Sumber Daya Air (Studi Kasus Pengadaan tanah Untuk Pembangunan Bendungan Semantok Di Kabupaten Nganjuk-Jawa Timur”, Prosiding SEMATEKSOS 3 "Strategi Pembangunan Nasional Menghadapi Revolusi Industri 4.0"

[17]. Faizal, "Diskursus Pemberdayaan Masyarakat", Ijtimaiyya, Vol. 8, No. 1, Februari 2015

[18]. Ewamendri,"Pendekatan, Strategi, dan Metode Pendekatan Masyarakat", 5 Maret 2017, https://elwamendri.wordpress.com/2017/03/05/pen 
dekatan-strategi-dan-metode-pemberdayaanmasyarakat/, diakses 20 November 2019.

[19]. PKSEN-BATAN, "Laporan Evaluasi Tapak Aspek Demografi”, LET 2015

[20]. Siti Alimah, Mudjiono, Ristiana Dwi Hastuti, "Persepsi Masyarakat Sekitar Kawasan Puspiptek Serpong Terhadap Potensi Dampak Sosial Rencana
Pembangunan RDNK”, Prosiding Seminar Nasional Teknologi Energi Nuklir, Padang 18 September 2019. 